\title{
Penerapan Media Pembelajaran pada Materi Memformat Dokumen Pengolah Kata di SMK Negeri 17 Samarinda
}

\author{
Andi Rustandi*, Muhammad Luthfi Anwar \\ Program Studi Pendidikan Komputer, Fakultas Keguruan dan Ilmu Pendidikan, \\ Universitas Mulawarman \\ *Corresponding Author. Email: andi.rustandi@unmul.ac.id
}

\begin{abstract}
This study aims to analyze the feasibility of learning media on the subject of computer skills and information management based on the Google Classroom application for class $\mathrm{X}$ students majoring in Pharmacy at SMK Negeri 17 Samarinda. This research method uses a qualitative approach. Data collection techniques using questionnaires, interviews, observation, and documentation. The data analysis technique used in this research was qualitative and quantitative descriptive analysis.. The results of this study are: The feasibility of implementing Google Classroom learning media on the material for formatting word processing documents at SMK Negeri 17 Samarinda which has been tested for feasibility with the feasibility analysis technique using a Likert scale. based on an assessment by a media expert with a total score of 79 or $92.9 \%$ of the maximum total score so that it is in the very feasible category, an assessment by a material expert with a total score of 47 or $94 \%$ of the maximum score so that it is in the very feasible category, and an assessment by students with a mean total score of 63.5 or $84.67 \%$ of the total maximum score so that they fall into the very feasible category. Based on this assessment, it can be said that the application of Google Classroom learning media to the material for formatting word processing documents that will be applied to SMK Negeri 17 Samarinda is declared "Very Appropriate" to be used.
\end{abstract}

Abstrak: Penelitian ini bertujuan untuk menganalisis kelayakan media pembelajaran pada mata pelajaran keterampilan komputer dan pengelolaan informasi berbasis aplikasi Google Classroom untuk siswa kelas X jurusan Farmasi di SMK Negeri 17 Samarinda. Metode penelitian ini menggunakan pendekatan kualitatif. Teknik pengumpulan data menggunakan angket, wawancara, observasi, dan dokumentasi. Teknik analisis data penelitian ini menggunakan analisis deskriptif kualitatif dan kuantitatif. Hasil dari penelitian ini adalah: Kelayakan penerapan media pembelajaran Google Classroom pada materi memformat dokumen pengolah kata di SMK Negeri 17 Samarinda yang telah di uji kelayakan dengan teknik analisis kelayakan dengan menggunakan skala likert. berdasarkan penilaian oleh ahli media dengan jumlah skor 79 atau 92,9\% dari jumlah skor maksimum sehingga masuk dalam kategori sangat layak, penilaian oleh ahli materi dengan jumlah skor 47 atau 94\% dari jumlah skor maksimum sehingga masuk dalam kategori sangat layak, dan penilaian oleh siswa dengan nilai rerata jumlah skor 63,5 atau $84,67 \%$ dari jumlah skor maksimum sehingga masuk dalam kategori sangat layak. Berdasarkan penilaian tersebut maka dapat dikatakan bahwa penerapan media pembelajaran Google Classroom pada materi memformat dokumen pengolah kata yang akan diterapkan pada SMK Negeri 17 Samarinda dinyatakan "Sangat Layak" untuk digunakan.

How to Cite: Rustandi, A., \& Anwar, M. (2021). Penerapan Media Pembelajaran pada Materi Memformat Dokumen Pengolah Kata di SMK Negeri 17 Samarinda. Jurnal Teknologi Pendidikan : Jurnal Penelitian dan Pengembangan Pembelajaran, 6(1). doi:https://doi.org/10.33394/jtp.v6i1.3535

doi https://doi.org/10.33394/jtp.v6i1.3535

This is an open-access article under the CC-BY-SA License.

\author{
Article History \\ Received: 01-03-2021 \\ Revised: 30-03-2021 \\ Published: 14-04-2021
}

Learning Media, Google

Classroom, Document

Formatting, Word

Processor.

\section{Sejarah Artikel}

Diterima: 01-03-2021

Direvisi: 30-03-2021

Diterbitkan: 14-04-2021

\section{Kata Kunci:}

Media Pembelajaran, Google Classroom, Memformat Dokumen, Pengolah Kata.

\section{Key Words:}




\section{Pendahuluan}

Kurikulum 2013 dikembangkan untuk memberikan pengalaman belajar seluasluasnya bagi peserta didik, yang memiliki titik tekan pada peningkatan dan penyeimbangan soft skill serta hard skill meliputi kompetensi sikap, keterampilan, dan pengetahuan (Fadlillah, 2014: 16). Pola pikir pembelajaran pada kurikulum 2013 mengalami penyempurnaan, yaitu dari penyampaian pengetahuan menuju pertukaran pengetahuan, sehingga menyebabkan terjadinya pergeseran paradigma pembelajaran (Kemendikbud, 2014: 5). Menurut buku karangan Yamin (2013: 61) pergeseran paradigma pembelajaran yang dimaksud adalah dari pembelajaran behavioristik kepada pembelajaran konstruktivistik, yang menjadikan pembelajaran lebih berfokus pada peserta didik (student centered) daripada pembelajaran yang berfokus pada pendidik (teacher centered). Sehingga dalam implementasi kurikulum 2013, peserta didik dituntut untuk berperan aktif dalam upaya memenuhi kebutuhan kompetensi yang harus dicapai.

Penelitian dimulai dengan pengamatan peneliti ataupun observasi. Hasil observasi yang dilakukan di SMK Negeri 17 Samarinda dan hasil wawancara yang dilakukan dengan guru di SMK Negeri 17 Samarinda diperoleh data bahwa di sekolah tersebut memiliki fasilitas 3 lab komputer, proyektor di masing-masing kelas, serta ruang teori sebanyak 31 kelas di dalam sekolah. Metode guru mengajar masih menggunakan metode ceramah dan presentasi menggunakan Powerpoint.

Aplikasi powerpoint tidak memiliki menu yang dapat digunakan untuk membuat soal evaluasi. Siswa-siwa khususnya pada jurusan Farmasi kelas X juga merasa kurang berminat selama proses pembelajaran karena merasa bosan dengan media yang digunakan dan metode mengajar yang guru gunakan selama proses pembelajaran.

Google Classroom merupakan sistem manajemen pembelajaran untuk sekolahsekolah dengan tujuan memudahkan pembuatan, pendistribusian dan penilaian tugas secara paperless. Google Classroom berperan sebagai media atau alat yang dapat digunakan oleh pengajar dan siswa untuk menciptakan kelas online atau kelas secara virtual, dimana dosen dapat memberikan pengumuman maupun tugas ke mahasiswa yang diterima secara langsung (real time) oleh mahasiswa tersebut. Yang membedakan Google Classroom dengan Klasiber yaitu dengan Klasiber mahasiswa tidak dapat mengetahui informasi yang di sampaikan oleh dosen secara langsung (real time) karena sistem dari Klasiber sendiri menggunakan website, sehingga mahasiswa harus login terlebih dahulu untuk mengetahui apakahada informasi atau tugas terbaru dari dosen. Untuk Google Classroom, sistem yang digunakan tidak hanya website namun juga dalam bentuk aplikasi yang dapat digunakan dalam smartphone dimana akun dari mahasiswa yang menggunakan akan login secara terus menerus sehingga jika dosen memberikan materi, tugas atau pengumuman, mahasiswa dapat menerima notifikasi secara otomatis.

Menurut penelitian yang dilakukan oleh Izenstark dan Leahy (2015), desain dari Google Classroom sudah tidak asing lagi bagi siswa-siswa karena sudah menggunakan beberapa produk dari Google via akun Google Apps. Siswa-siswa sangat menyukai bagaimana konektivitas antara Google Classroom dengan akun Google Drive. Peserta didik tidak perlu khawatir untuk menyimpan dokumen-dokumen dalam komputer kelas dikarenakan dengan fitur menyimpan secaraotomatis (autosave) dan kegunaan dari Drive membuat tugas-tugas lebih mudah disimpan dan terorganisir 


\section{Metode Penelitian}

Jenis Penelitian yang digunakan dalam penelitian ini adalah pendekatan kualitatif, dimana pengambilan data dilakukan secara alami dan data yang diperoleh berupa kata-kata dangambar. Sesuai dengan pengertian kualitatif itu sendiri yang bermaksud untuk memahami fenomena tentang apa yang dialami oleh subjek penelitian misalnya, perilaku, persepsi, motivasi, tindakan, dan lain-lain. Secara holistic pendekatan kualitatif dilakukan dengan cara deskripsi dalam bentuk kata-kata dan bahasa pada suatu konteks khusus yang alamiah dengan memanfaatkan berbagai metode alamiah. Sebagaimana dikemukakan di atas untuk pendekatan dalam penelitian. Ada pula jenis penelitian berdasarkan metode yaitu deskrptif. Menurut Arifin (2014: 42) penelitian deskriptif yang digunakan untuk menggambarkan (to describe), menjelaskan dan menjawab persoalan-persoalan tentang peristiwa yang terjadi saat ini, baik tentang fenomena sebagaimana adanya maupun analisis hubungan antara variabel dalam suatu fenomena. Dengan kata lain, perubahan atau manipulasi dilakukan terhadap variable bebasdanpengaruhnya diamati pada variable terikat.

Penerapan media Google Classroom dalam penelitian memastikan apakah media tersebut dapat bermanfaat dan menambah referensi dalam hal media pembelajaran meliputi alat tes berupa aplikasi Google Classroom dan juga angket yang digunakan kepada siswa untuk memperoleh data berupa tanggapan respon subjek terhadap hasil penerapan.

Teknik pengumpulan data yang digunakan dalam penelitian ini antara lain adalah;

1) Kuisioner (Angket)

Kuisioner merupakan teknik pengumpulan data yang dilakukan dengan cara memberi seperangkat pernyataan atau pertanyaan tertulis kepada responden untuk menjawabnya. Kuisioner (angket) yang digunakan dalam penelitian ini adalah angket tertutup yang berbentuk checklist. Dimana di dalam angket tersebut terdapat sederet pernyataan atau pertanyaan dan responden tinggal membubuhkan tanda centang $(\sqrt{ })$ pada kolom yang sesuai dengan pendapat responden. Data yang diambil melalui instrumen ini adalah untuk mengukur minat belajar siswa, serta validasi kelayakan media yang digunakan di dalam kelas.

2) Wawancara

Wawancara digunakan sebagai teknik pengumpulan data apabila peneliti ingin melakukan studi pendahuluan untuk menentukan permasalahan yang harus diteliti, dan juga apabila peneliti ingin mengetahui hal-hal dari responden yang lebih mendalam dan jumlah respondennya sedikit. Metode ini digunakan untuk mencari informasi tentang kondisi darana dan prasarana, dan kendala yang dihadapi guru dalam pelaksanaan kegiatan pembelajaran. Wawancara ini ditujukan kepada Wakil Kepala sekolah bidang Hubungan Masyarakat SMK Negeri 17 Samarinda.

\section{3) Observasi}

Observasi yaitu teknik pengumpulan data mempunyai ciri yang spesifik bila dibandingkan dengan teknik yang lain. Sutrisno Hadi mengatakan bahwa, observasi merupakan suatu proses yang kompleks, suatu proses yang tersusun dari berbagai proses biologis dan psikologis. Dua diantaranya yang terpenting adalah proses-proses pengamatan daningatan.Observasi disini dilakukan untuk mendapatkan gambaran nyatatentang lokasi dan proses belajar mengajar yang berlangsung di SMK Negeri 17 Samarinda serta sarana dan prasarana yang tersedia untuk proses kegiatan belajar dan mengajar. 
4) Dokumentasi

Dokumentasi merupakan suatu teknik pengumpulan data denganmenghimpun dan menganalisis dokumen-dokumen, baik dokumen tertulis,gambar, maupun elektronik. Sejumlah besar data dan fakta tersimpandalam bahan yang berbentuk dokumentasi. Sifat utama data tersebut tidak terbatas ruang dan waktu.

Instrumen penelitian yang digunakan adalah berupa kuisioner atau angket. Kuisioner atau angket merupakan teknik pengumpulan data yangdilakukan dengan cara memberi seperangkat pertanyaan atau pernyataantertulis kepada responden untuk dijawab. Instrumen kuisioner pada penelitian penerapan ini digunakan untuk memperoleh data dari ahli media, ahli materi, dan siswa sebagai bahan mengevaluasi media pembelajaran yang dikembangkan. Data kuantitatif yang diperoleh melalui kuisioner penilaian dianalisis dengan teknik analisis deskriptif kuantitatif yang diungkapkan dalamdistribusi skor dan presentase terhadap kategori skala penilaian yang telah ditentukan.

Data yang telah terkumpul dari hasil penelitian harus dianalisis menggunakan dua metode yaitu sebagai berikut:

1) Analisis Deskriptif Kualitatif

Adapun data kualitatif dalam penelitian ini yaitu berupa paparan tentang hasil penerapan media tersebut kepada siswa yang dilakukan dengan menggunakan pendekatan kualitatif, kemudian setelah data diperoleh maka langkah selanjutnya adalah menganalis adata. Analisis data yang digunakan adalah analisis data deskriptif kulitatif dan data yang diperoleh dalam penelitian ini berupa hasil mengenai repon dan tanggapan tentang penerapan media Google Classroom (alat tes) dari hasil angket. Data tambahan yang diperoleh dari wawancara terstruktur dengan siswa dan guru beserta foto dokumentasi sebagai pertimbangan. Adapun teknik analisis data untuk penelitian kualitatif menurut Milesdan Huberman (2009) adalah sebagai berikut:

a) Reduksi Data

Reduksi data, diartikan sebagai proses pemilihan, pemusatan perhatian pada penyederhanaan, dan transformasi data yang muncul dari catatan-catatan tertulis di lapangan selama penelitian berlangsung. Data yang di peroleh dari hasil observasi, angket, wawancara, dan dokumentasi dikumpulkan dalam catatan yang kompleks, kemudian dengan reduksi, penulis mengambil data pokok yang penting.Tahap ini dilakukan untuk mengukur data, memfokuskan pada hal-hal penting. Mereduksi data berarti merangkum, memilih hal pokok, fokus pada hal yang penting, dicari pola dan temanya dan membuang yang tidak perlu.

b) Penyajian data

Data yang diperoleh setelah dianalisis kemudian diambil simpulannya untuk mengetahui tujuan dari penelitian tercapai atau belum. data hasil reduksi data dan triangulasi kemudian dianalisis dengan analisis deskriptif. Selanjutnya, data hasil analisis disajikan dalam bentuk terstruktur sehingga data mudah dipahami. Penyajian data adalah penyajian sekumpulan informasi yang memberi kemungkinan adanya penarikan kesimpulan dan pengambilan tindakan. Data yang diperoleh hasil tes praktik disajikan dalam bentuk pilihan ganda (multiplechoice).

c) Penarikan kesimpulan

Dari data yang diperoleh kemudian diolah secara sistematis dan mudah dipahami, sehingga dapat ditarik kesimpulan dari penelitian yang sedang dilakukan. 
2) Analisis Kuantitatif

Analisis kuantitatif yaitu analisis data dengan mengadakan perhitungan-perhitungan yang relevan dengan masalah yang dianalisis. Analisis kuantitatif digunakan untuk menganlisis data yang terkumpul dari pengujian aplikasi seperti angket. Data dari pengujian aplikasi dianalisis untuk mendapatkan gambaran tentang kelayakan aplikasi tersebut. Data untuk variabel kelayakan dari pengujian yang dilakukan menggunakan skala pengukuran Likert dengan pilihan respon skala lima. Skala ini dapat memberikan alternatif jawaban dari soal instrumen dengan gradasi jawaban dari sangat positif hingga sangat negatif. Pilihan respon skala lima mempunyai variabilitas respon yang lengkap sehingga mampu mengungkap perbedaan sikap responden secara lebih maksimal. (Eko Putro: 2015). Data kualitatif yang diberikan responden diubah dalam bobot skor yang ditentukan, seperti pada tabel skala likert berikut :

Table 1. Skala Likert

\begin{tabular}{|l|c|}
\hline Skala Jawaban & Nilai \\
\hline Sangat Tidak Layak & 1 \\
\hline Kurang Layak & 2 \\
\hline Cukup Layak & 3 \\
\hline Layak & 4 \\
\hline Sangat Layak & 5 \\
\hline
\end{tabular}

Dari tabel kategori penilaian skala likert diatas maka akan dihitung persentase ratarata tiap komponen dengan menggunakan rumus berikut:

$$
\mathrm{P}=\frac{\sum \chi}{\sum \chi \mathrm{i}} \times 100 \%
$$

Keterangan :

$\mathrm{P}=$ presentase skor (dibulatkan)

$\sum \chi=$ jumlah nilai jawaban responden dalam satu aspek

$\sum \chi \mathrm{i}=$ jumlah skor ideal dalam satu aspek

Adapun kriteria persentase untuk menentukan apakah media tersebut layak untuk digunakan dapat dilihat pada tabel berikut:

Table 2. Rentang Kriteria Interpretasi

\begin{tabular}{|l|l|}
\hline \multicolumn{1}{|c|}{ Angka } & \multicolumn{1}{c|}{ Kriteria Interprestasi } \\
\hline $0 \%-20 \%$ & Sangat Tidak Layak \\
\hline $21 \%-40 \%$ & KurangLayak \\
\hline $41 \%-60 \%$ & CukupLayak \\
\hline $61 \%-80 \%$ & Layak \\
\hline $81 \%-100 \%$ & Sangat Layak \\
\hline
\end{tabular}

Menghitung skor kriteria dengan cara:

$$
\mathrm{K}=\frac{\mathrm{P}}{\mathrm{Q}} \times 100 \%
$$


Keterangan :

$\mathrm{K}=$ Kriteria interprestasi skor

$\mathrm{P}=$ Jumlah dari (Frekuensi responden $\times$ Skor jawaban)

$\mathrm{Q}=$ Hasil dari (Skor tertinggi $\times$ Jumlah keseluruhan responden)

Langkah selanjutnya adalah mengubah skor rata-rata menjadi nilai kualitatif. Kriteria pengubahan skor rata-rata menurut Eko Putro (2014), pada tabel berikut:

Table 3. Konversi Skor ke Dalam Nilai Skala 5

\begin{tabular}{|c|c|}
\hline Interval & Kategori \\
\hline$M i+1,8 \mathrm{SB} i<\mathrm{X}$ & Sangat Layak \\
\hline$M i+0,6 \mathrm{SB} i<\mathrm{X} \leq M i+1,8 \mathrm{SB} i$ & Layak \\
\hline$M i-0,6 \mathrm{SB} i<\mathrm{X} \leq M i+0,6 \mathrm{SB} i$ & Cukup \\
\hline$M i-1,8 \mathrm{SB} i<\mathrm{X} \leq M i-0,6 \mathrm{SB} i$ & Kurang \\
\hline $\mathrm{X} \leq M i-1,8 \mathrm{SB} i$ & Sangat Kurang \\
\hline
\end{tabular}

Keterangan:

$\mathrm{X}=$ Rata-rata perolehan skor

$\mathrm{Mi}=$ Meanideal

$\mathrm{SB} i=$ Simpangan Baku ideal

Dalam hal ini, jika harga Midan $\mathrm{SB} i$ disubstitusikan kedalam kriteria kevalidan, maka dapat dituliskan sebagai berikut:

Penentuan kriteria $\quad$ : Skor maksimal ideal $=5$

Skor minimal ideal $=1$

$\mathrm{Mi}=\frac{1}{2}$ (Jumlah skor maks ideal + Jumlah skor min ideal)

$\mathrm{M} i=\frac{1}{2}(5+1), \quad$ jadi $\quad \mathrm{M} i=3$

$\mathrm{SB} i=\frac{1}{6}$ (Jumlah skor maks ideal - Jumlah skor min ideal)

$\mathrm{SB} i=\frac{1}{6}(5-1) \mathrm{jadiSB} i=0,67$

Penilaian kelayakan penerapan media pembelajaran Google Classroom pada materi memformat dokumen pengolah kata di SMK Negeri 17 Samarinda ditentukan dengan nilai minimal B (Baik). Jika nilai rata-rata dari ahli media, ahli materi, dan siswa memperoleh nilai B, maka penerapan media pembelajaran Google Classroom pada materi memformat dokumen pengolah kata di SMK Negeri 17 Samarinda dinyatakan layak.

Untuk pengabsahan data penelitian ini menggunakan triangulasi. Moleong (2005) menyatakan bahwa triangulasi adalah teknik pemeriksaan keabsahan data yang memanfaatkan sesuatu yang lain di luar data untuk keperluan pengecekan atau pembanding data itu agar hasil penelitian yang diperoleh mengarah pada kesimpulan yang sama. Patton (dalam Moleong, 2005:330) mengemukakan triangulasi dengan sumber berarti membandingkan dan mengecek balik derajat kepercayaan suatu informasi yang diperoleh melalui waktu dan alat yang berbeda dalam penelitian kualitatif. Penulis akan mengumpulkan data dari beberapa gabungan metode untuk mencari kesimpulan tentang penerapan media Google Classroom dan sisi kebermanfaatan dalam inovasi pendidikan.

\section{Hasil Penelitian dan Pembahasan}

Penelitian yang dilakukan memiliki tujuan untuk meneliti kelayakan penerapan media pembelajaran Google Classroom pada materi memformat dokumen pengolah kata di SMK 
Negeri 17 Samarinda. Penelitian ini diharapkan dapat membantu guru sebagai media dalam proses mengajar. Berikut adalah penjelasan hasil dari masing-masing tahapan pengembangan tersebut. Kegiatan analisis data uji kelayakan daripenerapan media pembelajaran Google Classroom pada materi memformat dokumen pengolah kata. Pengujian dilakukan oleh ahli media, ahli materi dan siswa. Adapun hasil pengujian untuk masing-masing penguji adalah sebagai berikut.

1) Analisis Data Uji Kelayakan Dari Ahli Media

Pengujian oleh ahli media menggunakan instrumen berupa angket dan diisi oleh 1 ahli media yaitu Bapak Eko Subastian, S.Pd, M.Kom meliputi beberapa aspek yaitu aspek kemudahan, aspek tulisan dan aspek tampilan,. Hasil uji kelayakan daribeberapa aspek pada ahli media adalah sebagai berikut.

a) Aspek Kemudahan

Penilaian aspek kemudahanterdapat 5 butir penilaian. Dengan demikian maka diketahui skor tertinggi ideal adalah 25, skor terendah ideal adalah 5, dan nilai simpangan baku ideal adalah 3,33. Berdasarkan pengujian, didapatkan skor total dari ahlimedia adalah 25. Kemudiandapat diketahui data kualitatif hasil skor dari pengujian yang dilakukan mendapatkan kategori "Sangat Layak" dan memenuhi aspek kemudahan.

b) Aspek Tulisan

Penilaian aspek tulisanterdapat 6 butir penilaian. Dengan demikian maka diketahui skor tertinggi ideal adalah 30 , skor terendah ideal adalah 6 , dan nilai simpangan baku ideal adalah 4. Berdasarkan pengujian, didapatkan skor total dari ahlimedia adalah 29. Kemudiandapat diketahui data kualitatif hasil skor dari pengujian yang dilakukan mendapatkan kategori "Sangat Layak" dan memenuhi aspek tulisan.

c) Aspek Tampilan

Penilaian aspek tampilanterdapat 6 butir penilaian. Dengan demikian maka diketahui skor tertinggi ideal adalah 30, skor terendah ideal adalah 6, dan nilai simpangan baku ideal adalah 4. Berdasarkan pengujian, didapatkan skor total dari ahlimedia adalah 25. Kemudiandapat diketahui data kualitatif hasil skor dari pengujian yang dilakukan mendapatkan kategori "Layak" dan memenuhi aspek tampilan.

2) Analisis Data Uji Kelayakan Dari Ahli Materi

Pengujian oleh ahli materi menggunakan instrumen berupa angket dan diisi oleh 1 ahli materi. Angket tersebut meliputi beberapaaspek yaitu aspek kesesuaian materi dan aspek kualitas materi. Hasil uji kelayakan daribeberapa aspek pada ahli materi adalah sebagai berikut.

a) Aspek Kesesuaian Materi

Penilaian aspek kesesuaian materiterdapat 4 butir penilaian. Dengan demikian maka diketahui skor tertinggi ideal adalah 20, skor terendah ideal adalah 4, dan nilai simpangan baku ideal adalah 2,67. Berdasarkan pengujian, didapatkan skor total dari ahlimateri adalah 18. Kemudian dapat diketahui data kualitatif hasil skor dari pengujian yang dilakukan mendapatkan kategori "Sangat Layak" dan memenuhi aspek kesesuaian materi.

b) Aspek Kualitas Materi

Penilaian aspek kualitas materiterdapat 6 butir penilaian. Dengan demikian maka diketahui skor tertinggi ideal adalah 30, skor terendah ideal adalah 6, dan nilai simpangan baku ideal adalah 4. Berdasarkan pengujian, didapatkan skor total dari ahlimateri adalah 29. Kemudian dapat diketahui data kualitatif hasil skor dari pengujian yang dilakukan mendapatkan kategori "Sangat Layak" dan memenuhi aspek kualitas materi. 
3) Analisis Data Pengujian Siswa

Pengujian kelayakan oleh siswa menggunakan instrumen berupa angket dan diisi oleh 20 orang siswa. Pada angket tersebut terdapat 15 butir penilaian. Dengan demikian maka diketahui skor tertinggi ideal adalah 75, skor terendah ideal adalah 15, dan nilai simpangan baku ideal adalah 10. Berdasarkan penilaian, didapatkan jumlah skor adalah 1270. Apabila dihitung nilai rerata jumlah skor didapatkan nilai 63,5. Rerata skor kemudian dapat diketahui data kualitatif hasil skor dari pengujian yang dilakukan mendapatkan kualitas sistem dengan kategori "Sangat Layak".

\section{Kesimpulan}

Kesimpulan yang diperoleh dari hasil penelitian ini adalah kelayakan penerapan media pembelajaran Google Classroom pada materi memformat dokumen pengolah kata di SMK Negeri 17 Samarinda yang telah di uji kelayakan dengan pendekatan skala likert. Penilaian oleh ahli media dengan jumlah 92,9\% masuk dalam kategori sangat layak, penilaian oleh ahli materi dengan jumlah 94\% masuk dalam kategori sangat layak, dan penilaian oleh siswa dengan nilai rerata jumlah skor 84,67\% masuk dalam kategori sangat layak. Dapat dikatakan penerapan media pembelajaran Google Classroom pada materi memformat dokumen pengolah kata di SMK Negeri 17 Samarinda "Sangat Layak" untuk digunakan.

\section{Saran}

Pemanfaatan ruang komputer perlu ditingkatkan pada proses belajar mengajar, karena berbasis online maka diharapkan siswa dapat memanfaatkan media pembelajaran Google Classroom untuk belajar di sekolah maupun di rumah agar lebih memahami materi. Adanya usaha bagi guru maupun pihak sekolah menggunakan media pembelajaran Google Classroom untuk proses belajar mengajar pada materi atau mata pelajaran yang lain.

\section{Daftar Pustaka}

Andi, S. (2015). Penerapan Media Pembelajaran Berbasis Aplikasi Google Classroom Untuk Mata Pelajaran Sistem AC di SMK Negeri 2 Klaten.: Skripsi.

Andi Rustandi, Asyril Asyril, Nurul Hikma. (2020). Pengembangan Media Pembelajaran di Sekolah Menengah Kejuruan Teknologi Informasi Airlangga Samarinda. JURNAL FASILKOM, 10(3), 297-300.

Arsyad, A. (2009). Media Pembelajaran. Jakarta: Rajawali Pers.

Asyhar, R. (2012). Kreatif Mengembangkan Media Pembelajaran. Jakarta: Referensi.

Darmadi, H. (2011). Metode Penelitian Pendidikan. Bandung: Alfabeta.

Fadillah, M. (2014). implementasi Kurkulum 2013 Dalam Pembelajaran SD/Mi, SMP/Mts \& SMA/MA. Yogyakarta: Ar-Ruzz Media.

Haris Abdul, d. (2009). Evaluasi Pembelajaran. Yogyakarta: Multi Pressindo.

Irwan, R. (2017). Penerapan Media Pembelajaran Berbasis Aplikasi Google Classroom Untuk Mata Pelajaran Dasar Dan Pengukuran Listrik Kelas X Di SMK Swasta Imelda Medan . : Jurnal.

Ismail, H. (2017). Penerapan Media Pembelajaran Menggunakan Multimedia Interaktif Google Classroom Pada Kompetensi Dasar Menerapkan Macam-Macam Gerbang Dasar Rangkaian Logika Mata Pelajaran Teknik Elektronika Dasar Di SMK Negeri 2 Surabaya. : Jurnal. 
Joesolo. (2013). Lectora Portable Microsoft Office 2013. Aplikasi Media Pembelajaran interaktif diakses dari: http://surakartahadiningrat.com/2013/04/membangunpembelajaraninteraktif/.

Kemendikbud. (2014). Materi Pelatihan Guru implementas Kurikulum 2013 tahun 2014 Mata Pelajaran Sejarah SMA/SMK . Jakarta: Badan Penerapan Sumber Daya Manusia Pendidikan dan Kebudayaan dan Penjaminan Mutu Pendidikan .

Kusuma CR, 1. P. (2017). Bahan Ajar Keterampilan Komputer dan Pengelolaan Informasi Untuk SMA/MAK.: Ebook.

Latuheru, J. (1988). Media Pembelajaran. Jakarta: Departemen Pendidikan Nasional.

Munadi, Y. (2013). Media Pembelajaran Sebuah Pendekatan Baru. Jakarta: Referensi.

Rahyubi, H. (2012). Teori-Teori Belajar dan Aplikasi Pembelajaran Motorik . Bandung: Nusa Media.

Slameto. (2003). Belajar dan Faktor-Faktor Yang Mempengaruhinya . Jakarta: Rineka Cipta.

Sudjana, N. (2013). Penilaian Hasil Proses Belajar Mengajar. Bandung: Remaja Rosdakarya.

Sugiyono. (2012). Metode Penelitan Pendidikan. Bandung : CV. Alfabeta.

Yamin, M. (2013). Strategi dan Metode dalam Model Pembelajaran . Jakarta: Referensi Gaung Persada Press Group. 